\title{
Retrofitting of Reinforced Concrete Beams Using a Fiberglass Jacketing System
}

\author{
Titik P. Artiningsih ${ }^{1 *}$ Lirawati $^{1}$, and Navi Helmi ${ }^{1}$ \\ ${ }^{1}$ Civil Engineering Department Universitas Pakuan, Jl. Pakuan PO.Box 452, Ciheuleut, Bogor, 16144 \\ *Corresponding author: titikpenta@unpak.ac.id
}

(Received: $4^{\text {th }}$ May 2021; Accepted: $27^{\text {th }}$ May 2021)

\begin{abstract}
Building collapse that occurred mostly caused by structure failure in containment earthquake load. Factors that lead to the failure of the beam, among others is beam planning that does not calculate ductility or restraint, resulting decline of beams performance. One way to improve beam strength and ductility are to retrofit the beam by wrapping beams using fiberglass. Research aims to discover the increase amount of bending load capacity from concrete beam that has been retrofitted using jacketing fiberglass. Experimental testing was carried out on beam specimens with a cross section size of $150 \times 200 \mathrm{~mm}$ and a length of $1400 \mathrm{~mm}$. Three beam specimens were subjected to bending loads with a three point loading system, with different levels of damage, namely BL1 with collapse at level-1, BL2 at level-2, and BL0 at level-5 as a comparison. Then the BL1 and BL2 were retrofitted by being coated with 2 layers of fiberglass which were glued using epoxy resin. Beams BL-1 and BL-2 are then subjected to a bending test again until they reach level-5 collapse. The test results showed that retrofitted beams were able to increase flexural strength, BL-1 increased $115.15 \%$ from the original load and BL-2 increased $52.27 \%$ from the original load.
\end{abstract}

Keywords: beam; bending loads; three-point loading; retrofitting; fiberglass; jacketing

\section{Introduction}

As a result of the earthquake, many buildings were damaged. But structurally the building has not been destroyed because the columns are still standing, so the building can still be repaired. The buildings that were still standing after the earthquake showed various kinds of physical damage to the buildings. Damage in the form of cracking to shreds.

Many methods of increasing the strength of structural elements, one of which is the reinforcement is retrofit system. Tumialan (2001), the conventional retrofit methods can be divided according to the problems encountered, the repair of damage or improving the quality of the structure (strengthening-upgrading).The method of repairing crack damage is by filling and injection of voids using epoxy or grouting. While strengthening or upgrading using the grouting method with portland cement material non-shrink and epoxy, external reinforcement with steel plates, or surface coating using cement paste or shotcrete.

According to El-Dakhakhni (2004), another retrofit method is the addition of mass and stiffness, causing the beam-column portal to be at a greater level of seismic force capacity. This method is considered impractical and its use is limited to certain types of structures because it requires expertise in implementation, and is high in cost

In line with the development of material technology, now there is Fiber Reinforced Polymer (FRP) as an alternative to retrofit materials. There are three types of FRP, which is Carbon Fiber Reinforced Polymer (CFRP), Glass Fiber Reinforced Polymer (GFRP), or Aramid Fiber 
Reinforced Polymer (AFRP). Advantages of FRP is to have a thin thickness, the ratio of strength to weight is relatively large, high rigidity, and easy operation. FRP that is easily available and economical is fiberglass. There are various types of fiberglass, but the one commonly used as a retrofit is the E-glass type. There is a C-glass type fiberglass which is more economical than the E-glass type. Therefore, it was investigated the use of C-glass fiberglass as a retrofit for reinforced concrete beams.

\section{Problem Formulation}

Based on the background of this study, this study aims to determine the ability of the C-type fiberglass as a jacketing material to restore or increase the strength of reinforced concrete beam structural elements that have been damaged due to pure bending loads.

\section{Research Methodology}

The research method used is an experimental method. The research object was reinforced concrete blocks which were fixed using fiberglass woven roving type CWR-400 (type-C glass). Fiberglass woven roving CWR-400 is used because in terms of C-type fiberglass costs more economical than other fibers such as fiberglass-type-E, carbon fiber and aramid fiber.

The specimens were 3 reinforced concrete beams with a cross-sectional dimension of $15 \times 20 \mathrm{~cm}$ and a length of $140 \mathrm{~cm}$. The test carried out is a pure bending test with an incremental monotonic loading system to different levels of damage, wich consists of the level of damage 1, 3 and 5, as shown in Table 1.

Table 1. Damage Rating Criteria for Column and Beam Components

\begin{tabular}{cl}
\hline $\begin{array}{c}\text { Level of } \\
\text { Damage }\end{array}$ & \multicolumn{1}{c}{ Description of Structural Component Damage } \\
\hline 1 & - visible hair cracks on the concrete surface (crack width $<0.2 \mathrm{~mm}$ ) \\
\hline 2 & $\begin{array}{l}\text { - visible cracks on the concrete surface (crack width approx. } 0.2-1.0 \\
\mathrm{~mm})\end{array}$ \\
\hline 3 & - local destruction of the cover concrete \\
& - very clear cracks (crack width approx. 1 - 2mm) \\
\hline 4 & - very real concrete destruction with visible concrete reinforcement \\
& - cover concrete crushed \\
& - reinforcement bent \\
& - vertical deformation of the column (wall) can be seen \\
& - visible floor drop and/or slope
\end{tabular}

The first beam specimen, coded BL0, is a reinforced concrete beam that will be subjected to a bending load up to a damage level of 5 , because the BL0 beam serves as a visual comparison of the total damage condition to the BL1 and BL2 specimens. The load on BL0 is the maximum load P1. The second beam, code BL1, is a beam that will be given a bending load up to a damage level of 1 with a load of P2. The third beam, code BL3, is a beam that will be given a bending load up to a damage level of 3 with a load of P3.

The reinforcement used is plain reinforcement $2 Q 8$ in the compressive area, and $2 Q 10$ in the tensile area, and stirrup reinforcement Q6-100 mm. Details of the test object can be seen as in Fig. 1. 


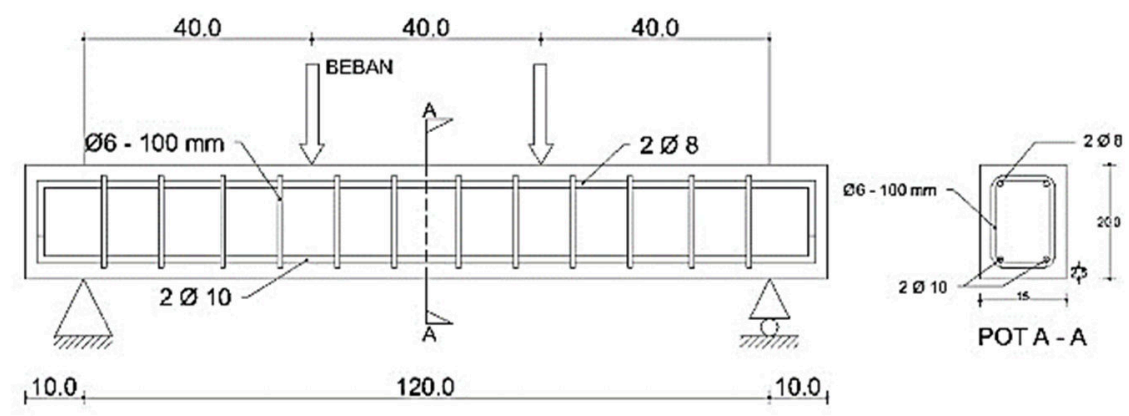

Fig. 1. Details of size and reinforcement specimen

\section{Flexural Strength Test}

Pure bending testing by means of three-point loading, the load is distributed to third span in the left and right split the beam into three, so that the middle receive pure bending loads, as shown in Fig. 2.

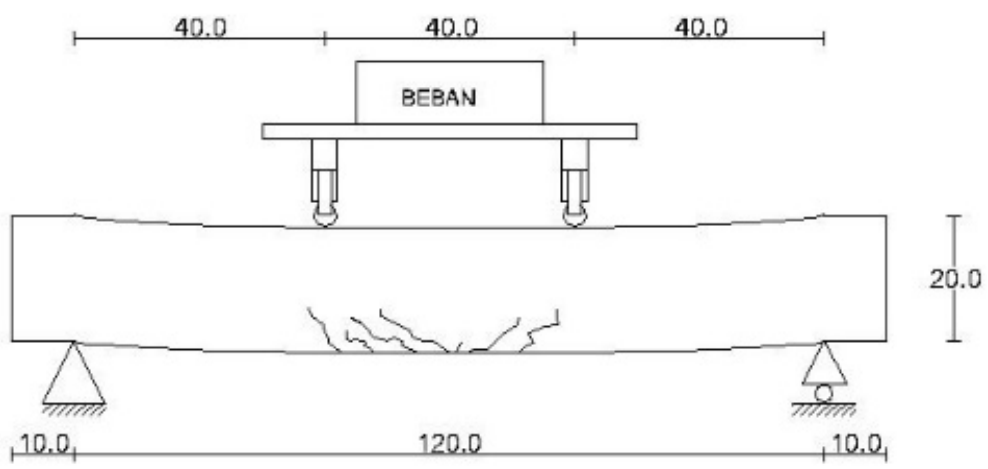

Fig. 2. Three-point pure bending loading

The amount of flexural strength is calculated based on the location of the crack:

- If the cracked or fractured plane is located in the central area (area 1/3 of the distance to the placement point), then the flexural strength of the concrete is calculated according to the following equation

$$
\sigma_{1}=\frac{P . L}{B . H^{2}}
$$

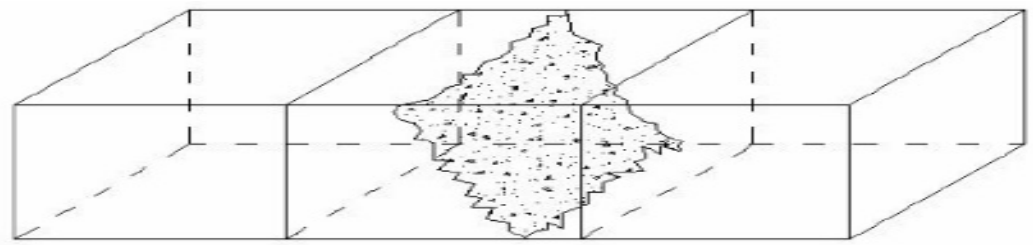

Fig. 3. Cracked or fractured at 1/3 Middle Span

- If the crack or fracture plane is located outside the center (area 1/3 of the distance between the placement point) and the distance between the center point and the fracture point is less than $5 \%$ of the distance between the placement points ), then the flexural strength of the concrete is calculated according to the following equation

$$
\sigma_{1}=\frac{P \cdot a}{B \cdot H^{2}}
$$




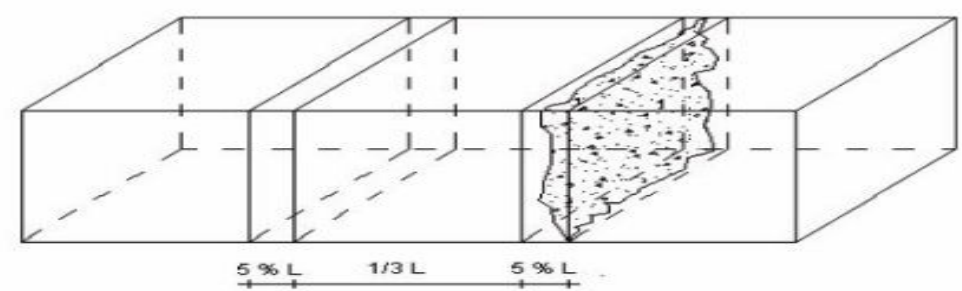

Fig. 4. Cracked or failured beyond $1 / 3$ center span and broken lines less then $5 \%$ of span

- If the crack or fracture occurs outside the center (area 1/3 of the distance between the placement point of the center) and the distance between the loading point and the breaking point is more than $5 \%$ of the span, the test results are not used.

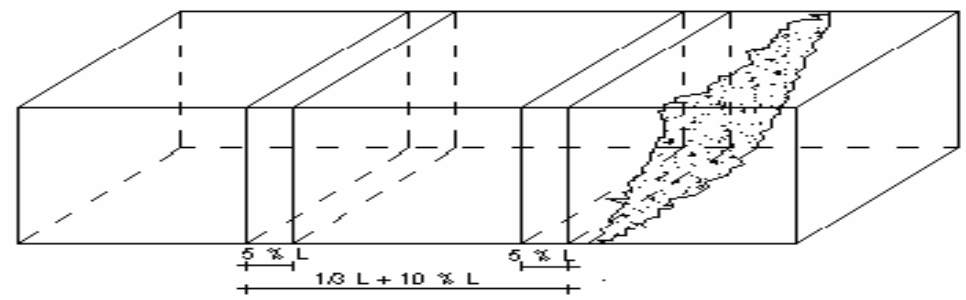

Fig. 5. Cracked or failured beyond $1 / 3$ center span and $>5 \%$ of span

\section{Beam repair}

Fiberglass jacketing is carried out after the test object is loaded and collapsed according to plan. The fiberglass is wrapped in 2 layers of blocks using epoxy resin.

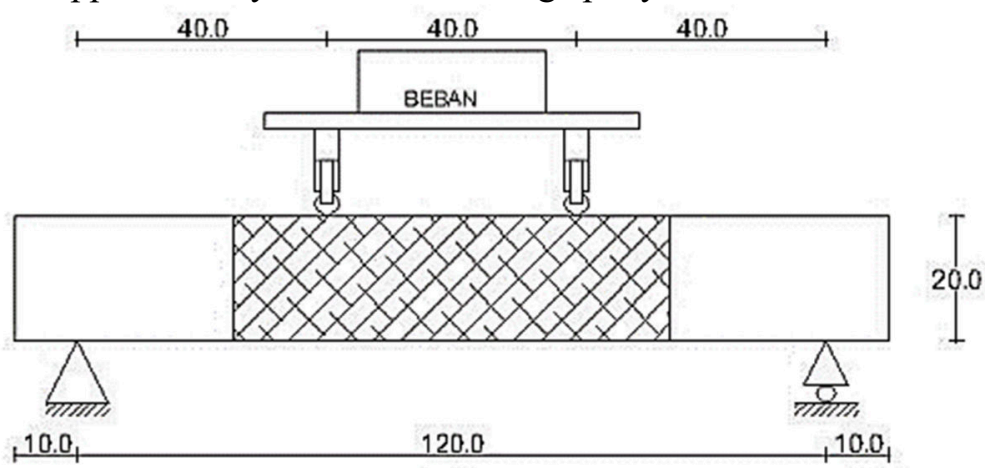

Fig. 6. Jacketing beam using WR400 fiberglass

\section{Analysis and Discussion}

\subsection{Flexural Strength Test Results}

BL1 test beam is a beam that is loaded with cracks with a width of $0,2 \mathrm{~mm}-0,5 \mathrm{~mm}$ and a crack length of $\pm 6,74 \mathrm{~cm}$ on the tensile side of the beam, which means that the test object is damaged with a damage ranking of 1 . The load used to reach the crack is $33 \mathrm{kN}$.

The BL2 test beam is a beam that is loaded with a crack of $0,50 \mathrm{~mm}-2,00 \mathrm{~mm}$ and a crack length of $\pm 14,47 \mathrm{~cm}$ on the left side and $6.74 \mathrm{~cm}$ on the right side, which means that the test object gets a damage ranking of 3 . The load used to achieve the crack was $44 \mathrm{kN}$. 


\subsection{Flexural Strength Test Results of Retrofit Beams}

Retrofitting was carried out on BL1 and BL2 beams by means of 2 layers of woven roving fiberglass jacketing CWR-400 using epoxy resin as adhesive.

From the graph in Fig. 7, it can be seen that the BL1 beam specimen with a damage level of 1 and a crack width of $0,20 \mathrm{~mm}$, at the second loading received a load of $71 \mathrm{kN}$. The beam has increased by $38 \mathrm{kN}$ or $115 \%$ from the first loading. The beam deflection is $1,8 \mathrm{~cm}$.

From the graph in Fig. 7, it can be seen that the BL2 beam specimen with a damage level of 3 and a crack width of $0,5-2,00 \mathrm{~mm}$, at the second loading received a load of $67 \mathrm{kN}$. The beam has increased by $23 \mathrm{kN}$ or $52.27 \%$ from the first loading. The beam deflection is $2,2 \mathrm{~cm}$.

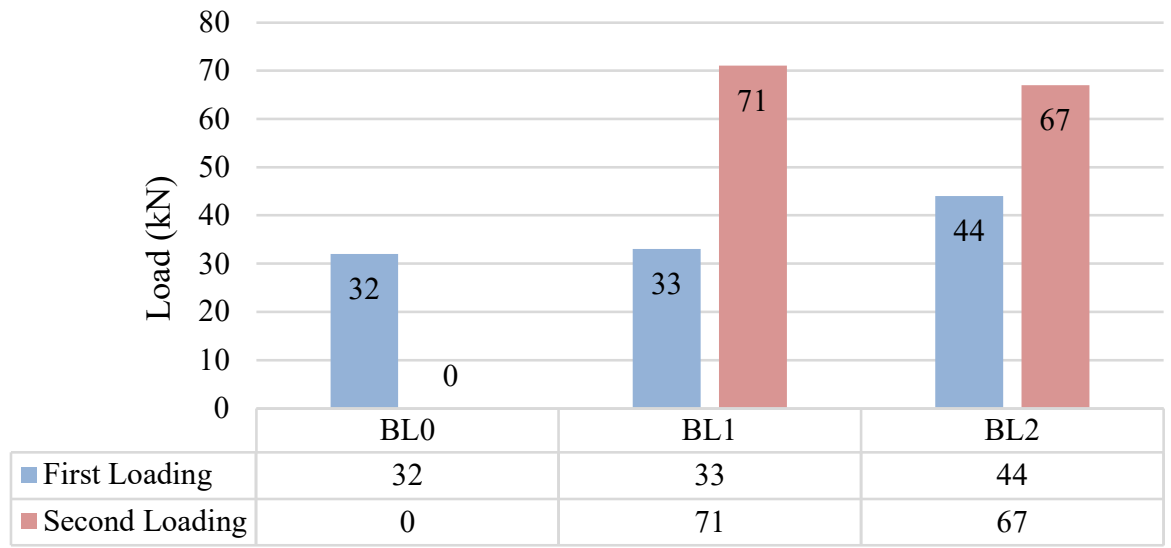

Fig. 7. comparison of bending loads before and after retrofit

\subsection{Crack Pattern}

BLR1 beam is retrofitted BL1 beam. BLR1 collapse beam flexural and shear failure simultaneously where properties differ collapse during the first loading only collapse bending. Shear failure can be seen because there is a large crack on the outer side of the beam which is not coated with fiberglass. The part of the fiberglass layer is not torn, instead the layer is debonded or the bond between the fiberglass layer and the concrete surface is released. Debonding can be seen because the fiberglass layer swells in the area that is experiencing cracks.

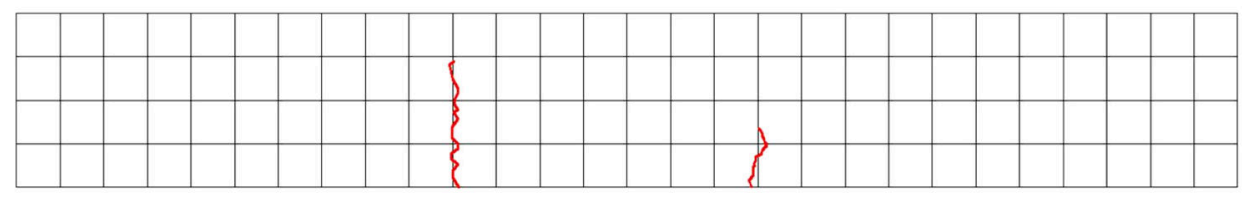

a. crack pattern at first loading

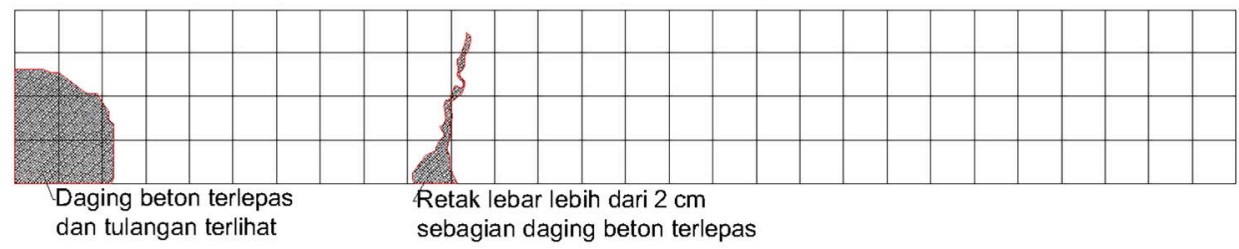

b. crack pattern at second loading

Fig. 8. comparison of beam crack pattern of BL1 and BLR1 


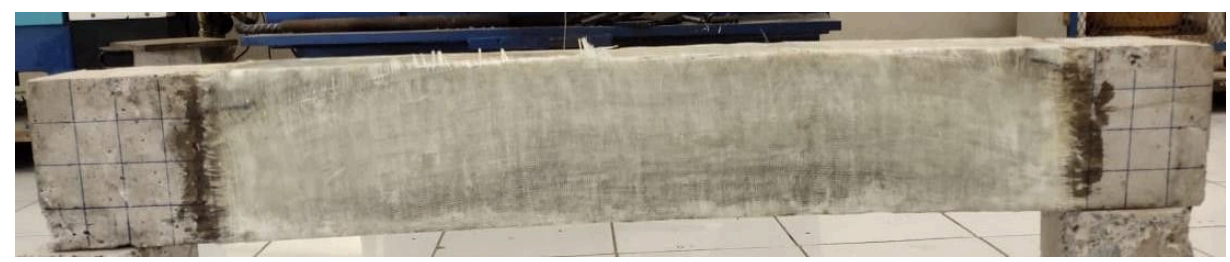

Fig. 9. BLR1 retrofit beam after loading, invisible cracks, hidden behind fiberglass

BLR2 beam is retrofitted BL2 beam. BLR beams had collapsed in a combination of bending and shear simultaneously. The collapse is different from during the first loading which only experienced flexible collapse. The shear failure can be seen clearly because the concrete cover on one outer side of the beam peels off so that the reinforcing bars are visible. Just like BL1, the fiberglass layer does not tear but the layer is debonded. Debonding can be seen because the fiberglass layer swells in the area that is experiencing cracks.

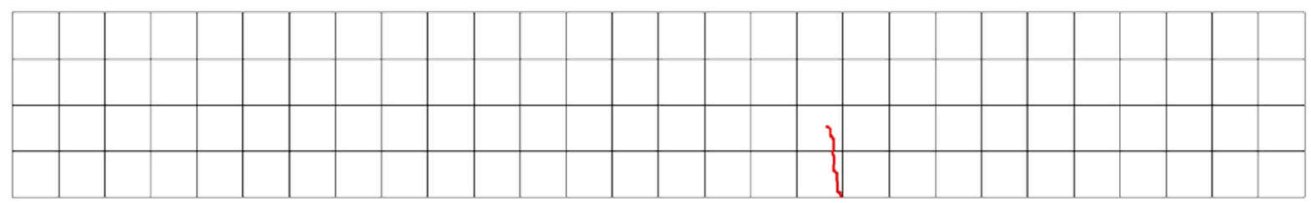

a. crack pattern at first loading

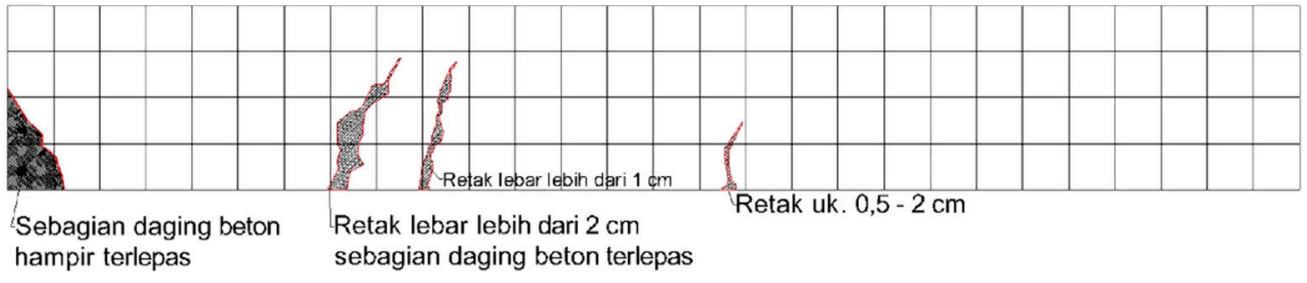

b. crack pattern at second loading

Fig. 10. comparison of beam crack pattern of BL2 and BLR2

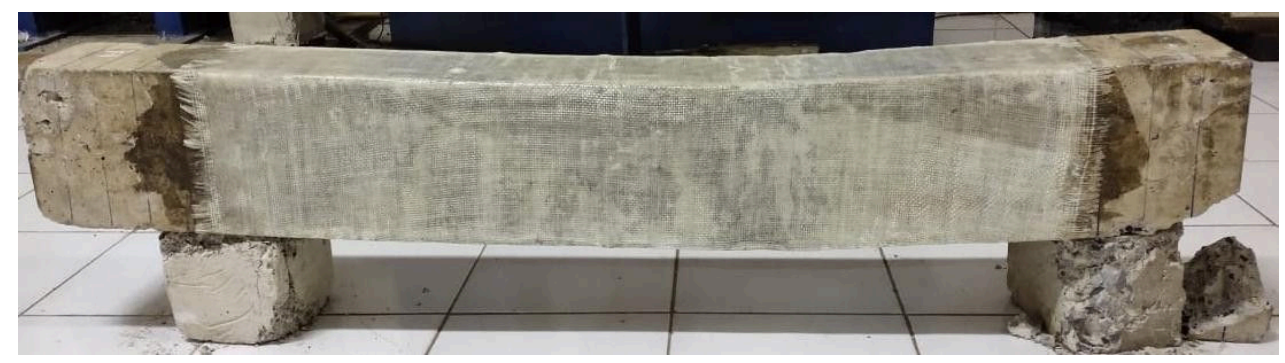

Fig. 11. BLR2 retrofit beam after loading, invisible cracks, hidden behind fiberglass

\section{Conclusion}

Retrofit method with jacketing system using woven roving fiberglass type CWR 400 can be used to repair beams up to level 3 damage. Fiberglass jacketing will increase the flexural capacity of the beam. On beam BL1 with damage level 1, increases flexural strength by up to $115 \%$, while BL2 with damage level 3 increases 52\%

Retrofit with fiberglass jacketing method has the disadvantage that cracks invisible beam so that the beam collapse could only be observed from the magnitude of the beam deflection. 


\section{Acknowledgments}

We would like to thank LPPM Universitas Pakuan

\section{References}

[1] Adang Kristianto, Yosafat Aji Pranata, Jeremy Julian, Nico Tandy Susilo (2015), Comparative Study of Increasing Axial Capacity of Reinforced Concrete Circle Column Given FRP Reinforcement and Pen Binder, Proc. of National Conf. of Civil Eng. 9 (KoNTekS 9), (in Indonesian).

[2] Al-Chaar, G. K., Lamb, G. E. (2002), Design of Fiber Reinforced Polymer for Seismic Rehabilitation of Infilled Concrete Structures, Engineer Research and Development Center, US Army Corps of Engineers, December.

[3] Basuki, Ariyadi (2013), Utilization of Composites from Reinforcing Materials between Glass Fibers and Aramid Fibers with Epoxy Resin Matrix for Reinforcement of Concrete Beam Models, Balai Besar dan Barang Teknik, Bandung (in Indonesian).

[4] Department of Public Works (2004), Preliminary Inspection of Damage to Reinforced Concrete Buildings Due to Earthquake (pd-t-11-2004-c), Public Works Research and Development Agency, Center for Settlement Research and Development, Bandung (in Indonesian).

[5] Dwisukmawati E., Tavio (2008), Normal Strength Rectangular Strength Concrete with Fine Mesh, Proc. of National Seminar of Technology Management VIII, Surabaya, August $2^{\text {nd }}$ (in Indonesian).

[6] El-Dakhakhni, Hamid, A., Elgaaly, M. (2004), Seismic Retrofit of Concrete-Masonry-Infill Steel Frames with Glass Fiber Reinforced Polymer, Journal of Structural Engineering, ASCE, Vol. 130(9) (in Indonesian).

[7] Jonie Tanijaya, Sepry Rantesalu (2008), Behavior of Infill Wall with Glass Fiber Reinforced Polymer Coating Reinforcement, Journal of Adiwidia, Universitas Kristen Indonesia Paulus, Vol.1(1), March (in Indonesian).

[8] Johanes Januar Sudjati, Hastu Nugroho, Paska Garien Mahendra (2013), Strengthening of Reinforced Concrete Columns with Glass Fiber Jacket to Increase Axial Load Capacity, Proc. of National Conf. of Civil Eng. 7 (KoNTekS 7), Surakarta, October (in Indonesian).

[9] Johanes Januar Sudjati, Randi Angriawan Tarigan, Ida Bagus Made Tresna (2015), Perbaikan Kolom Beton Bertulang Menggunakan Glass Fiber Jacket dengan Variasi Tingkat Pembebanan, Proc. of National Conf. of Civil Eng. 9 (KoNTekS 9), Makasar, October (in Indonesian).

[10] Mahendra, Paska Garien (2013), Strengthening of Reinforced Concrete Columns with Glass Fiber Jacket to Increase Axial Load Capacity, Universitas Atma Jaya Yogyakarta, Yogyakarta (in Indonesian).

[11] Mukahar, Reinforced Concrete Construction (Bending Element) (1994), Sebelas Maret University Press, Surakarta (in Indonesian).

[12] Sianipar, Marolop Tua (2009), Analysis of Reinforced Concrete Columns Reinforced with Carbon Fiber Reinforced Polymer, Departement of Civil Eng., USU (in Indonesian).

[13] Indonesian National Standard (2011), How to Test Normal Concrete Bending with Two Load Points (SNI 4431:2011), Badan Standarisasi Nasional (in Indonesian).

[14] Taufikurrahman, Parmo (2014), Improvement of Strength and Ductility of Reinforced Concrete Beams Using Glass Fiber Reinforced Polymer (GFRP) Strips, Universitas Wisnuwardhana Malang, Malang (in Indonesian).

[15] Teddy Boen \& Partners (2010), How to Repair a Simple Building Damaged by an Earthquake, Australia - Indonesia Facility for Disaster Reduction (in Indonesian).

[16] Titik P. Artiningsih (2017), Study on the Use of Ferro-cement for Retrofit of Reinforced Concrete Columns with Varied Loading Levels, Journal of Civil Eng., Vol.14(3), Universitas Atma Jaya Yogyakarta (in Indonesian). 
[17] Zaidir (2009), Repair and Reinforcement of Buildings After the West Sumatra Earthquake, Universitas Andalas, Padang (in Indonesian). 